\title{
Hanford Site Rare Plant Monitoring Report for Calendar Year 2012
}

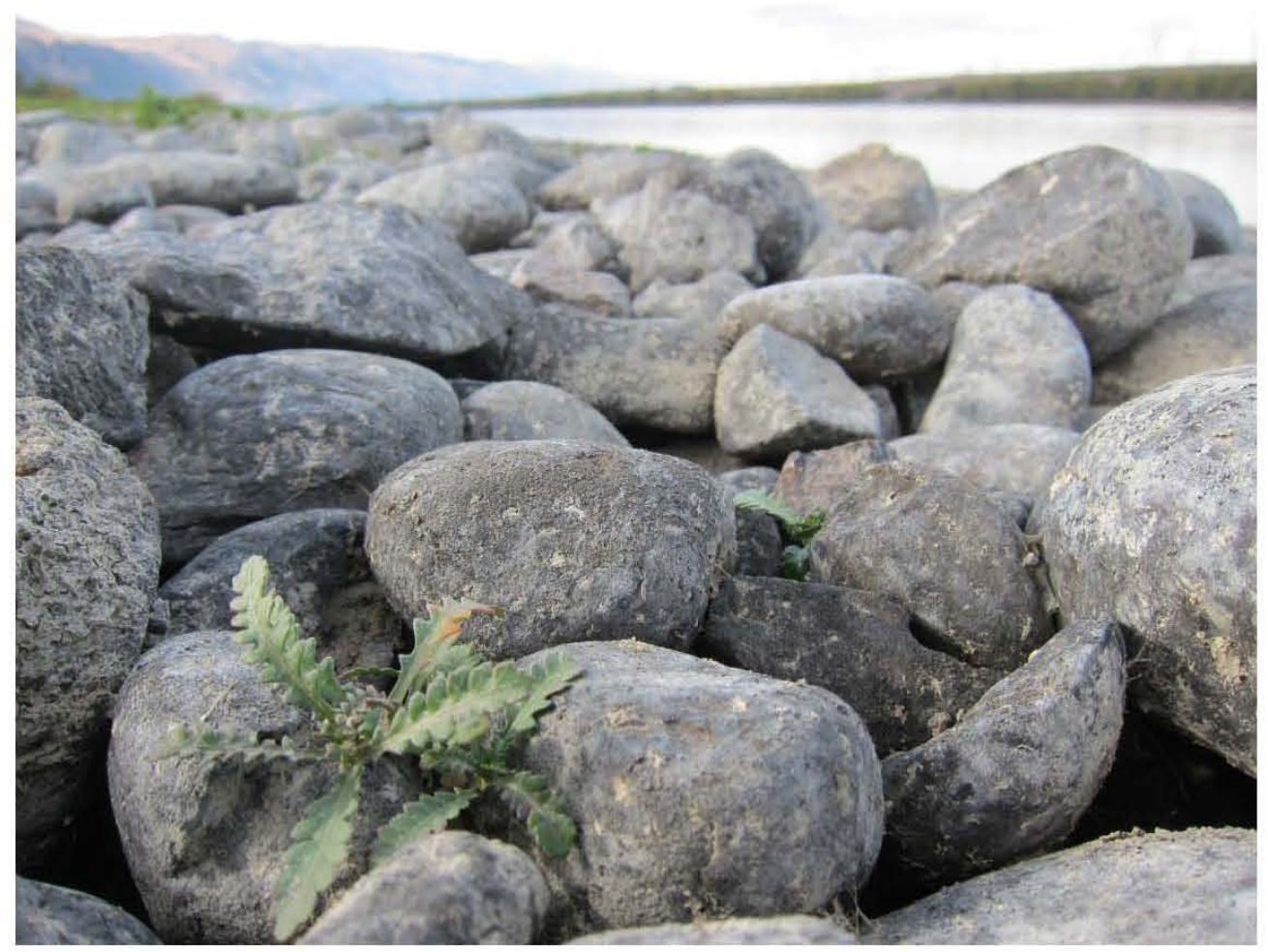

Prepared for the U.S. Department of Energy Assistant Secretary for Environmental Management Contractor for the U.S. Department of Energy under Contract DE-AC06-09RL14728

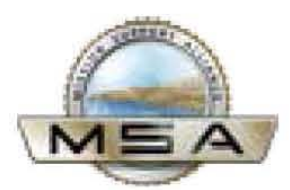

\section{P.O. Box 650}

Richland, Washington 99352 
HNF-54686

Revision 0

TRADEMARK DISCLAIMER

Reference herein to any specific commercial product, process, or service by trade name, trademark, manufacturer, or otherwise, does not necessarily constitute or imply its endorsement, recommendation, or favoring by the United States Government or any agency thereof or its contractors or subcontractors.

This report has been reproduced from the best available copy.

Printed in the United States of America

The cover photo is courtesy of Cole Lindsey. 


\section{Hanford Site Rare Plant Monitoring Report for Calendar Year 2012}

D. Salstrom, R. Easterly, C. Lindsey and J. Nugent Mssion Support Aliance

Late Publisted

March 2013

Prepared for the U.S. Department of Energy

Assistant Secretary for Environmental Management

Contractor for the U.S. Department of Energy

under Contract DE-AC06-09RL14728

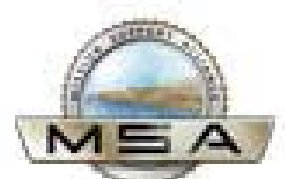

P.0. Box 650

Richland, Was hington 99352

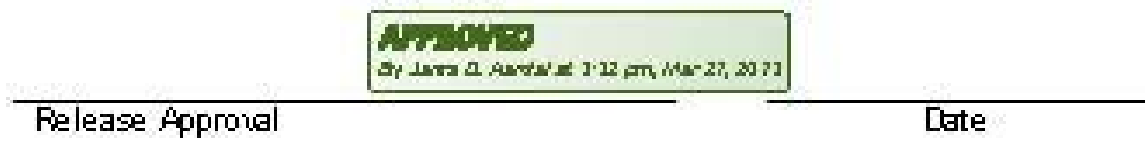




\section{Contents}

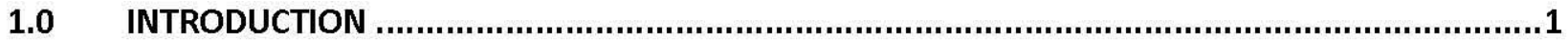

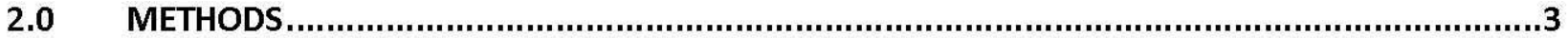

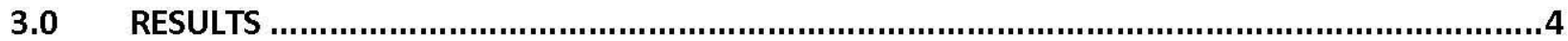

DISCUSSION

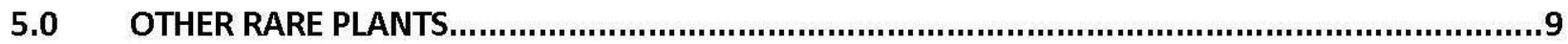

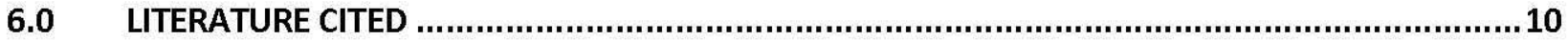

\section{Figures}

Figure 1. The Hanford Site in South-Central Washington State ............................................................. 1

Figure 2. Surveyed Area and Locations for Columbian Yellowcress in 2011 ............................................... 3

Figure 3. Surveyed Area and Locations for Columbian Yellowcress in 2012 ................................................ 5

Figure 4. Columbian Yellowcress in Bloom Along the Hanford Reach During 2012 ...................................... 6

Figure 5. Surveyed Area and Locations for Columbian Yellowcress from the Combined 2011/2012 Surveys

Figure 6. Columbian Yellowcress Covered in Sand and Sediment from Frequent Inundation . .8 


\subsection{Introduction}

Columbian yellowcress (Rorippa columbiae) is a rhizomatous perennial species that occurs along the lower shorelines of the Columbia River on the Hanford Site in south-central Washington State (Figure 1). It is endemic to Washington, Oregon, and California, is a Species of Concern for the USFWS and is considered to be endangered in Washington (WNHP 2011). Extensive damming of the Columbia River in Washington has eliminated its habitat along much of the shoreline. The species is currently known from two disjunct locations along the Columbia River: a relatively small occurrence below the Bonneville Dam and an extensive occurrence on the Hanford Reach, the latter of which is the most extensive of any of the species' populations.

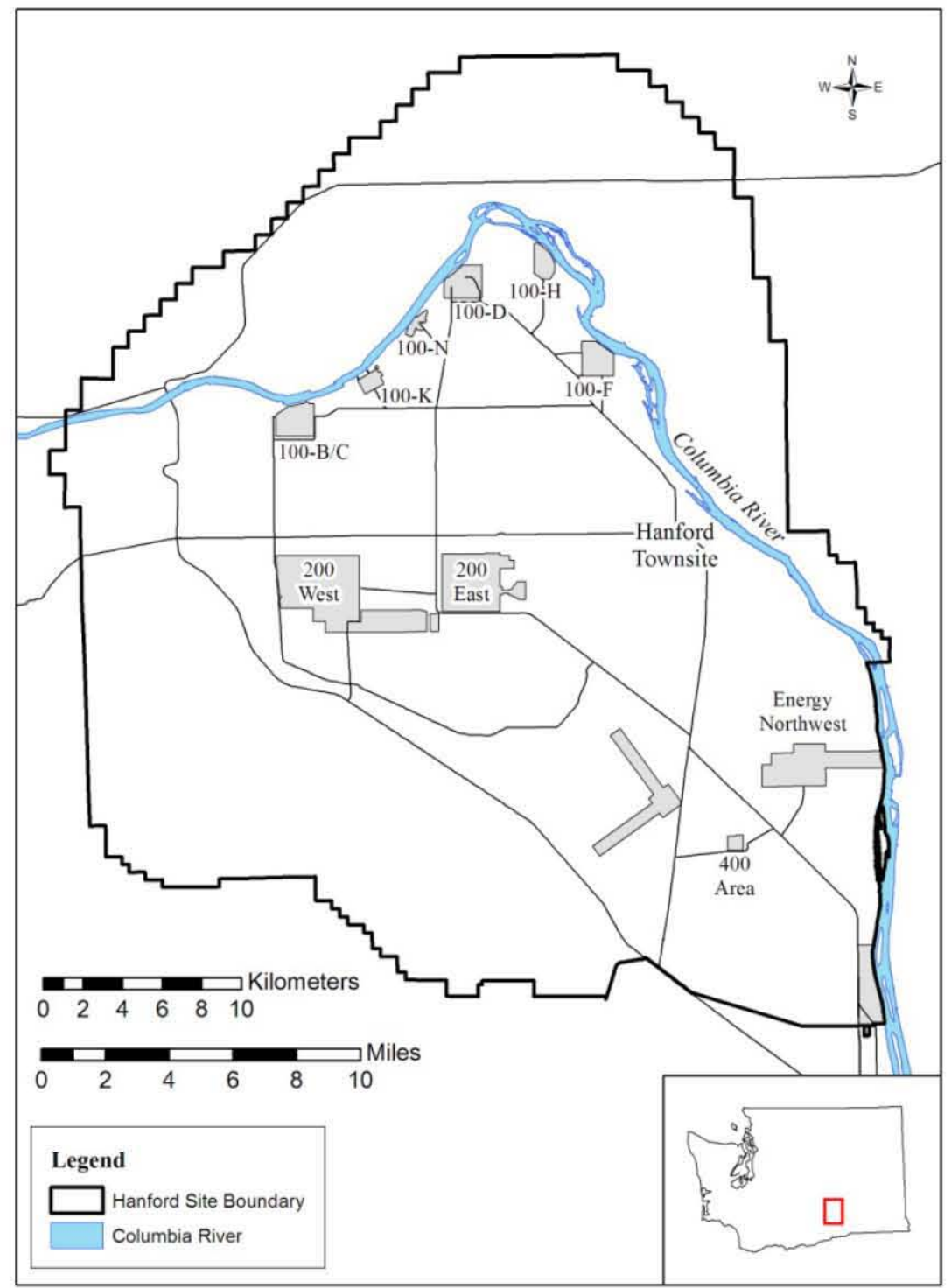

Figure 1. The Hanford Site in South-Central Washington State

Along the Hanford Reach, the species occurs in the open cobble of the lower-most vegetated zone. The sites generally occur where shoreline and channel topography combine to create a surging or accelerating river current (for example, gravel bars that jut into the river flow). 
The number of ramets can fluctuate widely from year to year, likely due to patterns of inundation and temperature during the growing season. Management of the river flow from upstream dams now regularly inundates the species' habitat on a daily cycle for extended periods during the summer. This has shifted the growing season into the late summer and fall when the habitat is more reliably and continuously exposed. More recently, the growing season has been abruptly curtailed in mid-October due to Reverse Load Factoring. Reverse Load Factoring is defined by the Hanford Reach Fall Chinook Protection Program (HRFCPP 2004) as "the intentional reduction of power generation during daylight hours and the corresponding increase in power generation during hours of darkness for the purpose of influencing the location of redds on Vernita Bar, during which the habitat is flooded on a daily cycle to influence placement of redds by fall Chinook salmon" (HRFCPP 2004). This results in low flows during daylight periods and high flows during the night, the "reverse" of a typical flow regime driven by power demand. Due to the shifted and truncated growing season, fruits of Columbian yellowcress seldom have a long enough/warm enough season to develop, and mature fruits have rarely been observed under this management strategy.

Prior to this inventory, mapped locations of the species' occurrences along the Hanford Reach were available in the 2010 Public Safety and Resource Protection (PSRP) Database, which was transferred from Pacific Northwest National Laboratory (PNNL) to Mission Support Alliance (MSA) in 2011, and in the Washington Natural Heritage Program (WNHP) Information System. Some of the larger concentrations of mapped Global Positioning System (GPS) points in the PSRP Database, however, likely represent multiple points within the same patches recorded during multiple years. Points located in inappropriate habitats (i.e., upland) are likely accounted for by the lower accuracy of GPS prior to May of 2000, when GPS Selective Availability was still active (NCOSPNT 2011). Polygons from the WNHP Information System were often created from maps provided by each surveyor before widespread use of GPS, and polygons were often created to capture multiple discrete occurrences within each polygon.

The species has been monitored over several years in plots at several locations on the Hanford Reach, including mid-Reach at Locke Island (Island 6) and 100-F Beach by PNNL and in the lower reach at Homestead (Island 13) and Plow (Island 12) Islands by the Bureau of Land Management (BLM) and the WNHP. Since the beginning of monitoring at Locke Island and 100-F Beach, ramet numbers declined radically, were low for a number of years then gradually increased, but have not reached ramet densities recorded in 1994 (PNNL 2010). The plots at Homestead and Plow islands have shown a sharp decline in the number of ramets between 1994 and 2002 (Caplow 2003). The most recently reported shoreline survey, apart from at established monitoring plots, was in 2001, when a "precipitous decline" of the species along the Reach downriver from White Bluffs Boat Launch was reported (Caplow 2003).

In 2011, a large portion of the Hanford Shoreline (south and west bank) of the Columbia River was thoroughly surveyed for the presence of Columbian yellowcress; islands and the other side of the river were not inventoried (Salstrom et al. 2012, Figure 2). A graded approach was used starting in areas of previously identified populations, then in areas with ideal habitat, followed by areas with less ideal habitat. A total of 43.7 miles $(70.3 \mathrm{~km})$ of the Hanford shoreline was surveyed, with 235 patches identified and approximately 90,000 ramets counted. The focus of the 2012 survey was to inventory the remaining sections of the Hanford shoreline not surveyed in 2011 in order to complete the entire length of the shoreline along the central Hanford Site. The resulting data and maps can update and integrate with existing information. The 2012 survey can also be used to help minimize potential impacts to this species from Hanford project activities along the shoreline, monitor population trends over time, and increase the understanding of the status and dynamics of this high priority species along the Hanford Reach. 
HNF-54686

Revision 0

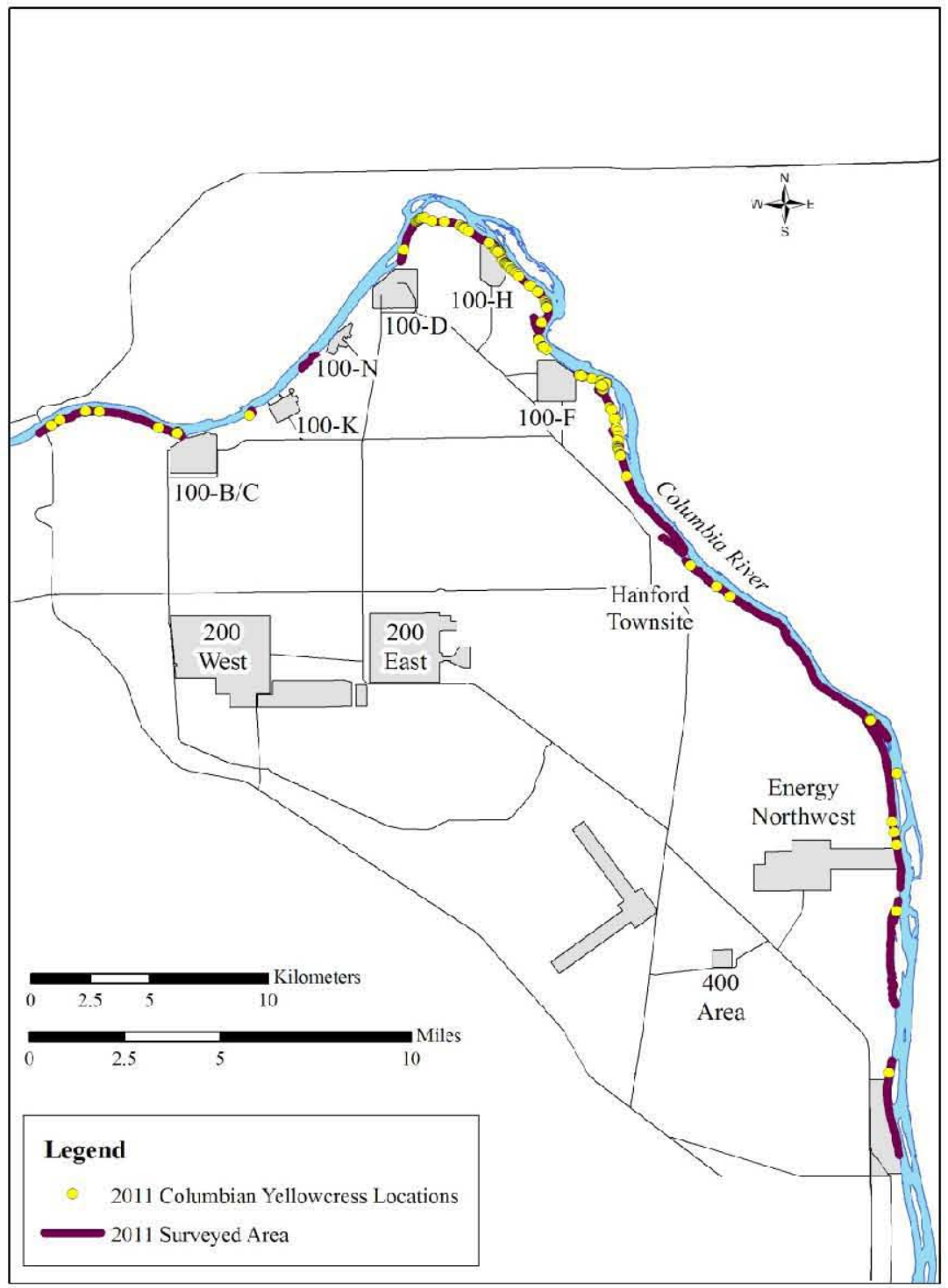

Figure 2. Surveyed Area and Locations for Columbian Yellowcress in 2011

\subsection{Methods}

Two locations identified during the 2011 survey were revisited during 2012 to determine whether the number of ramets was comparable between the two survey years. Occurrences identified in 2011 were recounted and measured in 2012 to ensure that ramet counts were similar between the two survey years.

Additional areas surveyed in 2012 were separated into relatively small sections of shoreline along the length of the Hanford shoreline of the Hanford Reach that were not surveyed during the 2011 inventory. "Hanford shoreline" refers to the Benton County shoreline of the Hanford Reach, on the right hand side of the river as one travels downstream. The survey area was shoreline with open cobble in and around the lower-most vegetated zone, an area from five to more than 100 feet wide depending on the slope of the riverbank. This zone is inundated by flows between $50-120 \mathrm{kcfs}$ (thousand cubic feet per second), as 
measured at the upstream Priest Rapids Dam. Surveys were conducted when flows were below 60 kcfs in order to avoid missing inundated occurrences.

When Columbian yellowcress patches were found, a GPS point was taken at the upstream/inland extent of the patch of ramets (or group of patches), and the area covered was recorded (length measured parallel to the direction of flow, width measured perpendicular to the direction of flow). Trimble GeoXT GPS units capable of sub-meter accuracy were used. Also recorded were the number of ramets (estimates were made at sites with large numbers), the range of ramet lengths, the number of ramets with flowers/fruits, and a range of the number of flowers/fruits per ramet. Photographs were taken to depict habitat characteristics (e.g., density of associated vegetation, cobble size, population locations and shoreline configuration). Larger patches were mapped as polygons, in addition to capturing the upstream/inland point.

\subsection{Results}

Two patches of Columbian yellowcress on the Hanford Reach were visited in both 2011 and 2012 to compare ramet counts between years: near Allerd Pumphouse (Rkm 615.4) and near White Bluffs Boat Launch (Rkm 593.3) (Figure 3). In 2012, the population near Allerd Pumphouse had 45 ramets present within a $5 \times 3 \mathrm{~m}$ area. At the same population in 2011, there were 60 ramets. In 2012, the population near White Bluffs Boat Launch had 105 ramets in a $2 \times 2 \mathrm{~m}$ area. At the same population in 2011, there were 100 ramets. This data shows that while annual variability does exist, ramet counts were relatively similar from 2011 to 2012 . This is likely due to the similar flow regimes of 2011 and 2012, which both had above average snowpack, high flows, and extended spring flooding seasons.

A total of 19.6 miles $(31.5 \mathrm{~km})$ of the Hanford shoreline were surveyed in 2012, with ten patches identified and approximately 1,250 ramets counted (Figure 3). It is not known how many individual plants this count represents due to the rhizomatous nature of the species. Two of these sites were identified previously in the WNHP database, and the remaining eight were newly identified locations. Eleven of the ramets had flowers and/or buds in the patches located during 2012, but no fruits were found (Figure 4). 
HNF-54686

Revision 0

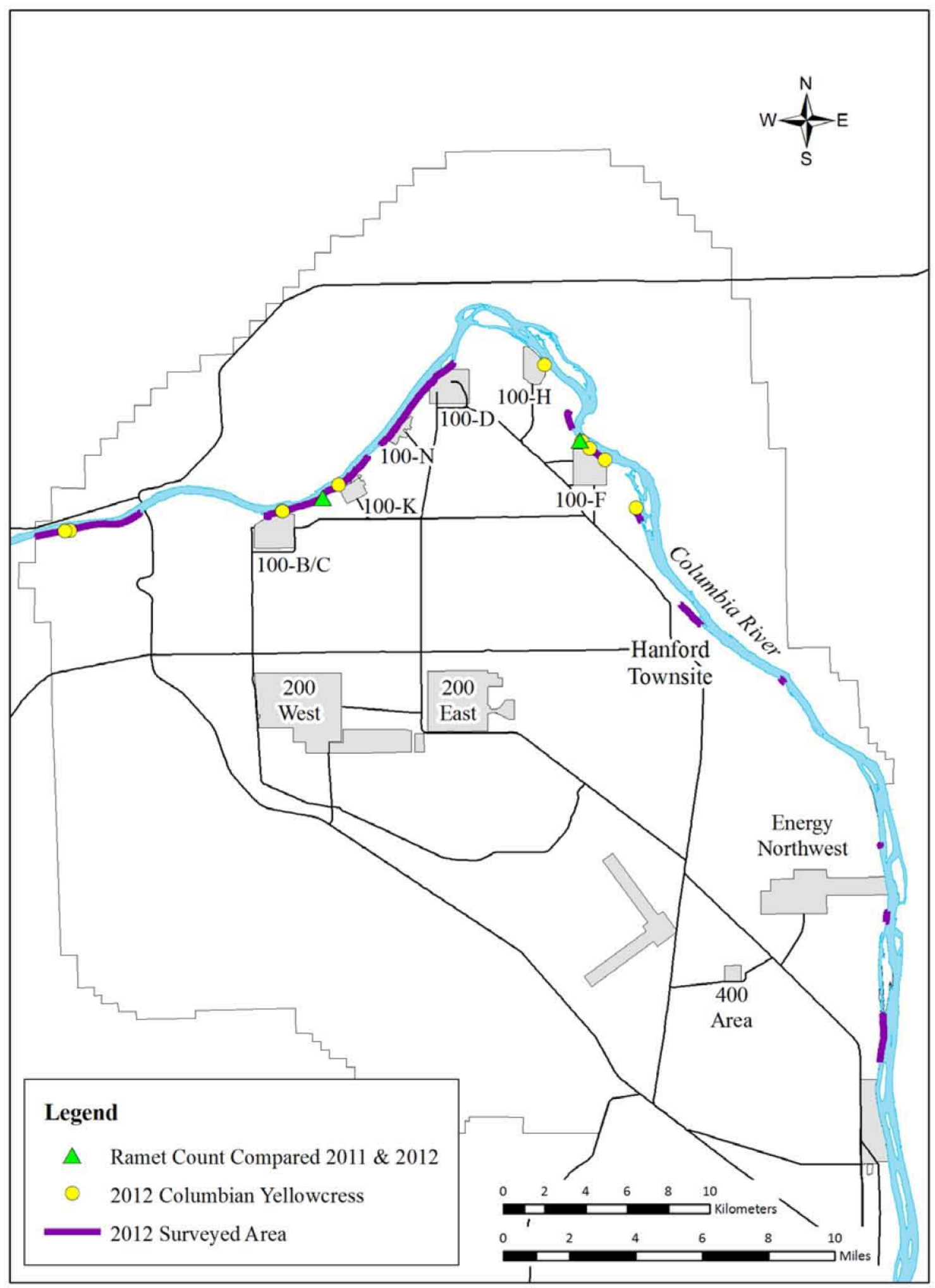

Figure 3. Surveyed Area and Locations for Columbian Yellowcress in 2012 


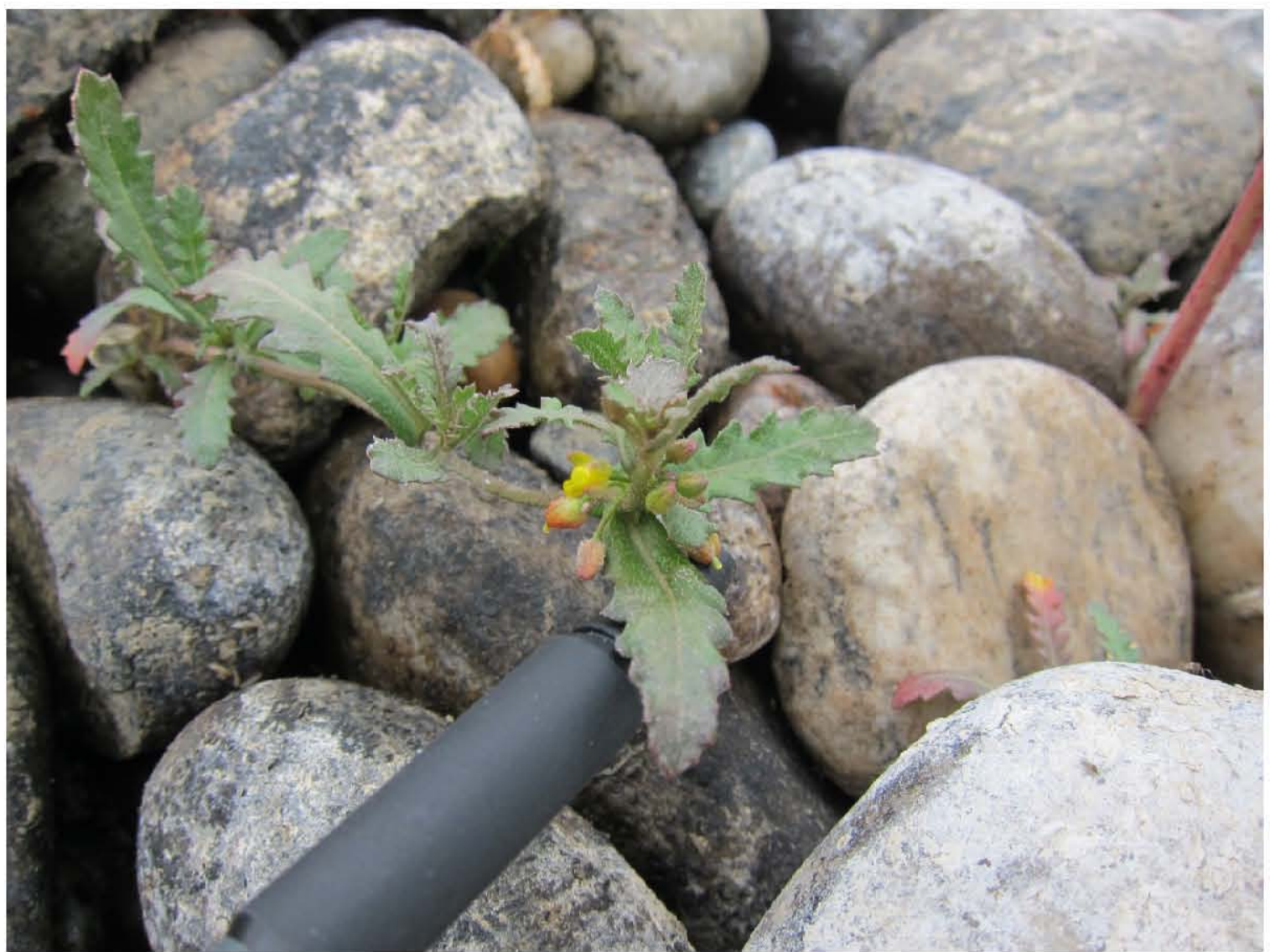

Figure 4. Columbian Yellowcress in Bloom Along the Hanford Reach During 2012

\subsection{Discussion}

Between the 2011 and 2012 surveys, the entire length of the Hanford Reach on the central Hanford side was surveyed for Columbian yellowcress, a total survey length of 63.3 miles $(101.8 \mathrm{~km})$. The length of the Columbia River along the survey area is approximately 47 miles $(75.6 \mathrm{~km})$, and the difference is made up by the undulating nature of the river shoreline which includes large sloughs. A total of 245 patches with approximately 91,250 ramets were recorded during the two surveys (Figure 5). This provides an up-to-date map of the current distribution of the plant within the described area, and a snapshot in time of the patch sizes and ramet abundance. This data not only informs future shoreline activities to ensure that impacts to Columbian yellowcress are avoided, but sets a baseline to compare population levels and distribution in the future. 
HNF-54686

Revision 0

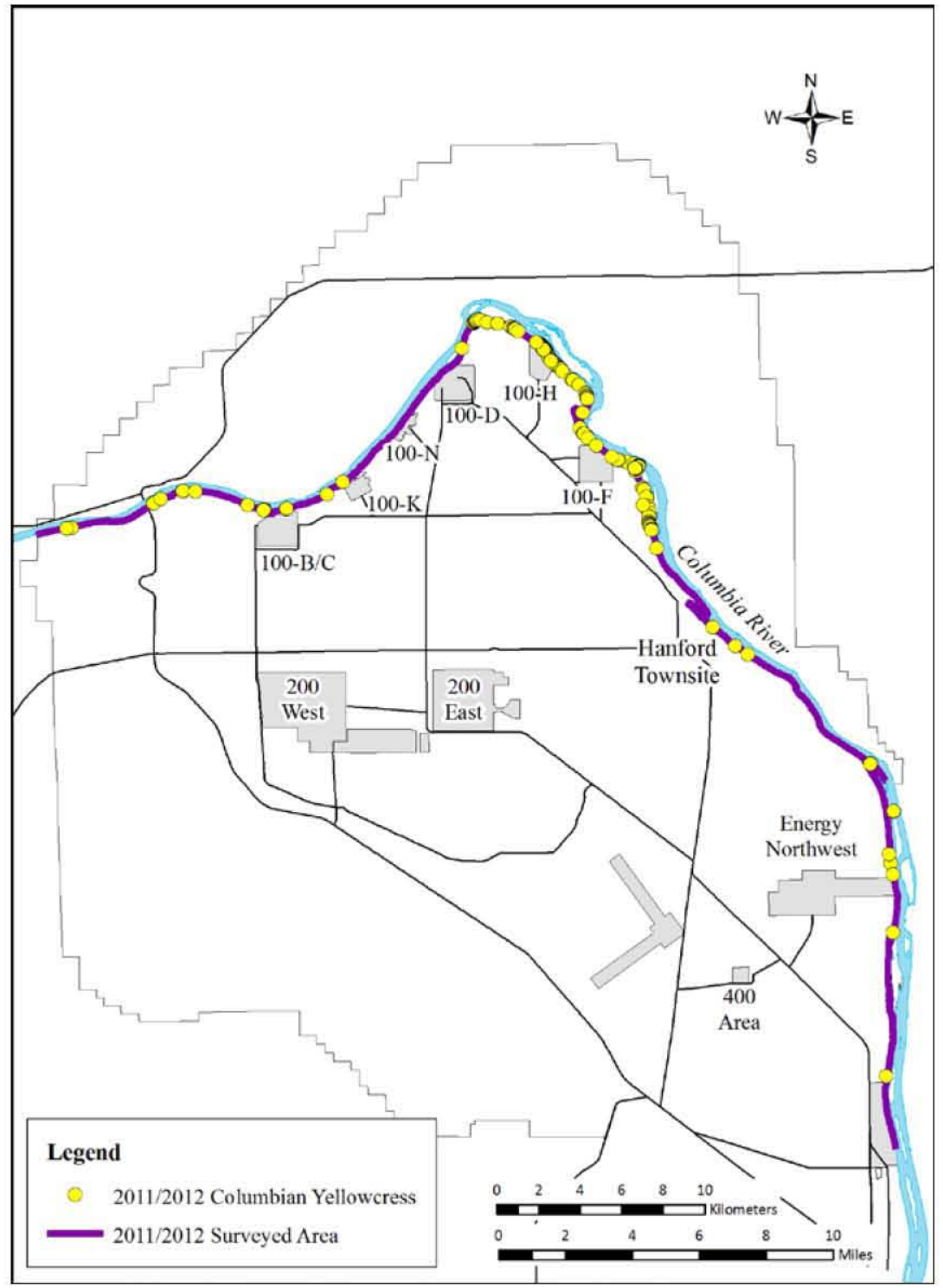

Figure 5. Surveyed Area and Locations for Columbian Yellowcress from the Combined 2011/2012 Surveys

Although Columbian yellowcress continues to occur regularly in the areas along the Hanford Reach where its microhabitat requirements exist and can be relatively abundant during certain years (e.g. 2011 and 2012), its lack of reproduction and recruitment are causes for concern. In 2012, as in 2011, the percentage of ramets with flowers and buds was low ( $0.6 \%$ and $0.1 \%$ respectively), and no mature fruits were observed. The 2012 survey was conducted late in the growing season, and the absence of mature fruits indicates that the species continues to lack the ability to reproduce via seed under the regulated flow conditions present on the Hanford Reach. Currently, the habitat is usually inundated until late summer, from which time it is still periodically submerged by water released during the day for power production by upriver dams. In addition, beginning in mid-October the habitat is inundated daily due to the Reverse Load Factoring flow regime conducted at the upstream Priest Rapids dam. Reverse Load Factoring is used, as part of the Vernita Bar Agreement, to encourage fall Chinook salmon (Oncorhynchus tshawytscha) to spawn deeper in the river. While the pre-dam river flow regime during 
summer was characterized by sustained low river levels, current management of the river typically inundates and exposes the species' habitat repeatedly, often daily (Figure 6). This management has shifted the primary growing period into the fall and has limited, if not halted, reproduction by seed.

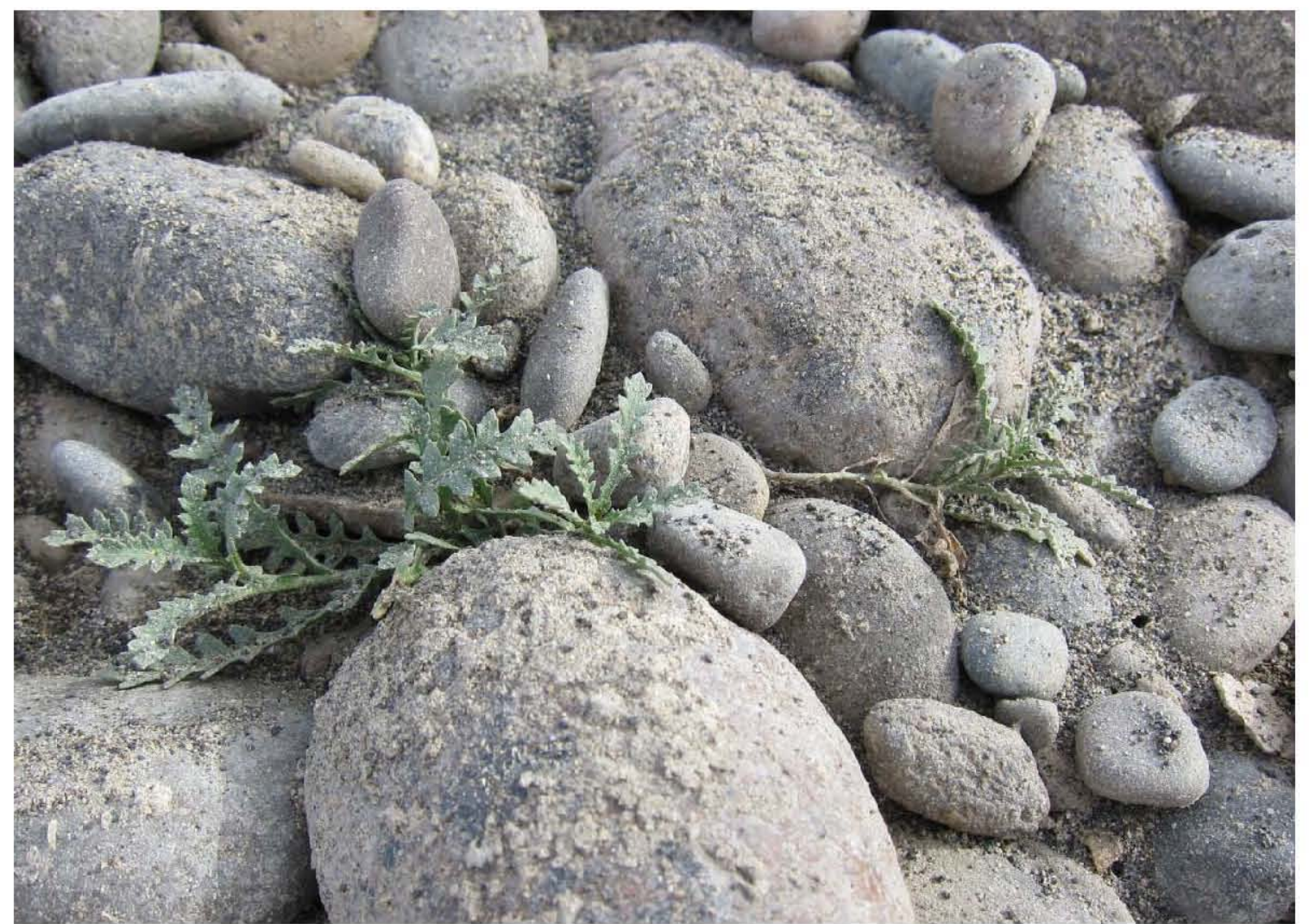

Figure 6. Columbian Yellowcress Covered in Sand and Sediment from Frequent Inundation

Long-term trends are often difficult to discern for a rhizomatous species that produces large fluctuations in the number of ramets from year to year, as with Columbian yellowcress. Annual differences in the river flow regime and air temperatures during the time the plants are exposed likely influence the number of ramets and amount of flowering that occurs along the Hanford Reach. Variations in the number of ramets were noted as early as 1984 (WNHP 2011).

Monitoring data indicate that the species has declined precipitously since 1994 in the lower portion of the Reach (Caplow 2003; Salstrom and Easterly personal observation, 2011). Another observation indicating decline of the species in the lower Reach is that the species has not been seen for many years at Ringold, where it had been abundant in the past (Rickard, personal communication). In contrast, PNNL's monitoring data in the middle portion of the Hanford Reach at Locke Island and 100-F-Beach indicated relative stability during recent years, albeit with lower ramet density than recorded during the mid-1990s (PNNL 2010). That data, together with results of this survey, suggest a possible differential status of the species along the Reach, with large declines in the lower portions of the Reach, and apparent current relative stability in the middle and upper portions of the Reach. The reason(s) for the apparent decline in the lower portions of the Reach relative to upriver are not understood. Potential contributors might include slumping along the White Bluffs. This may have altered the dynamics of river slope, flow, and subtle downriver trajectories of the river current and subsequent patterns of scour along the shoreline. The microhabitat of Columbian yellowcress along the shoreline appears to be 
determined by position relative to the current. While it is in the nature of a river to change course over time, the lack of seed production and the apparent lack of vegetative propagules in Columbian yellowcress suggest that it currently does not have the means to dynamically reestablish itself to take advantage of newly developed habitat, except for slight repositioning of established rhizomes into suitable microhabitat within the river profile.

Another factor in changing habitat may be the entrapment of sediment behind upriver dams, which essentially eliminates all but local deposits feeding into the Reach. This may have led to a net-erosion of shoreline material over time. A further cause may be a 'ripple' effect of inundation that causes an approximately eight-hour lag in inundation/exposure in the lower portions of the Reach in response to management at Priest Rapids Dam. A result of this delay from one end of the Reach to another, for example, is that during the fall Reverse Load Factoring, Columbian yellowcress habitat nearer to the dam is exposed near daybreak, while habitat downriver, such as at Homestead and Plow Islands, is typically not exposed until midday, further reducing its growing season there.

Future research considerations for Columbian yellowcress should include annual surveys for successful fruiting at several locations, including plants that occur at low and high flow levels. In addition, the relative abundance of ramets should be documented annually at several locations, and an inventory of the population should be conducted at least every three years. Although some work has been conducted on the islands and opposite shoreline (Grant/Franklin counties), these areas lack a large-scale continuous survey. An inventory of the species in these areas would contribute greatly to the overall picture of the status of this endangered species along the Hanford Reach. Additional data concerning habitat needs and dynamics (for example, patterns of scour and deposition) would also be useful to inform Columbian yellowcress management. This investigation could expand into an attempt to understand the effects of river management on the overall vegetation and habitat. This would involve analyzing changes in habitat from the vegetation map and informal plots (Easterly and Salstrom 1995), old photos (from the riparian zone and aerial), and other sources. Research could also help determine whether the potential reduction of habitat and lack of seed production are indicative of an overall degradation of the habitat along the river and whether the declines seen in the lower portion of the Hanford Reach will later be observed upriver. If continuing degradation is documented, recommendations for river management could be made that may reverse the potential for extirpation of this species along the Hanford Reach, while also managing for fall Chinook salmon and the requirements of upriver dams. Finally, the potential exists to grow plants in a garden and then outplanting them into appropriate habitat, using lessons learned from the 2011 out-planting on the BLM islands done by the USFWS (Heidi Newsome, USFWS, personal communication).

\subsection{Other Rare Plants}

Rare plant monitoring performed by MSA during 2012 was limited to Columbian yellowcress. Two other projects were conducted on the central portion of the Hanford Site that included rare plant inventories. These surveys were completed in support of the Midway-Benton No. 1 Rebuild Project (US DOE 2013) and for the installation of a natural gas pipeline to service the Waste Treatment Plant (WTP) (BPA 2013). These projects were conducted by contractors of the Bonneville Power Administration (BPA) for the Benton-Midway project and Cascade Natural Gas (CNG) for the natural gas pipeline installation. Rare plants were documented along the length of each project. The rare plant location data collected for each project will be incorporated into MSA's PSRP database for rare plants. A detailed description of the rare plant survey methods and results are available in the Biological Resource Study Summary Report for each project (PEC 2012 and EAS 2012). 
HNF-54686

Revision 0

\subsection{Literature Cited}

BLM, 2012, Unpublished monitoring records for Rorippa columbiae. Bureau of Land Management, Wenatchee, Washington.

Caplow, F., 2003, Studies of Hanford Rare Plants, 2002, Unpublished report prepared for the Washington Office of The Nature Conservancy, on file at the Washington Natural Heritage Office, Olympia, Washington.

Easterly, R. and D. Salstrom, 2006, Hanford Rare Plant Project: 2006 Remediation Site Inventory, DOE/RL-2007-21, prepared for the U.S. Department of Energy, Richland, Washington.

EAS, 2012, Hanford Natural Gas Pipeline Project: Summary Report of Biological Resources Survey (Proposed Esquatzel Route), prepared by Environmental Assessment Services, Richland, Washington.

HRFCPP, 2004, Hanford Reach Fall Chinook Protection Program Executed Agreement, Hanford Reach Fall Chinook Protection Program. Online at http://www.nwdwc.usace.army.mil/tmt/documents/wmp/2006/draft/app7.pdf.

NCOSPNT, 2011, Selective Availability, National Coordination Office for Space-Based Positioning, Navigation, and Timing, Washington, D.C., Online at http://www.gps.gov/systems/gps/modernization/sa/.

PNNL, 2010, Hanford Site Environmental Report for Calendar Year 2010, PNNL-20548, Pacific Northwest National Laboratory, Richland, Washington, Online at http://msa.hanford.gov/msa/FileDisplay.cfm?FileID=1467.

PNNL, 2011, Unpublished files and records of rare plants on the Hanford Site, Pacific Northwest National Laboratory, Richland, Washington, Provided to Mission Support Alliance May 9, 2011.

PEC, 2012, Midway-Benton No. 1/Benton-Othello No. 1 Transmission Line Rebuild Project Biological Resource Study Summary Report, Point Environmental Consulting, Seattle, Washington.

Salstrom, D. and R. Easterly, 1995, Riparian plant communities: south shore and islands of the Columbia River on the Hanford Site, WA. Prepared for The Nature Conservancy, Seattle, Washington.

Salstrom, D., R. Easterly, C. Lindsey, and J. Nugent, 2012, Rare Plant Monitoring Report for Calendar Year 2011, HNF-52260 Rev. 1, Prepared for the U.S. Department of Energy, Richland, Washington. Online at http://www.hanford.gov/files.cfm/HNF-52260 - Rev 01.pdf.

US DOE, 2013, Acquisition of a Natural Gas Pipeline and Natural Gas Utility Service at the Hanford Site, Richland, WA, and Notice of Floodplains and Wetlands Involvement, U.S. Department of Energy, Richland, Washington. Online at http://energy.gov/nepa/office-nepa-policy-and-compliance.

US DOE, 2011, Hanford Meteorological Station, US Department of Energy, Richland, Washington. Online at http://www.hanford.gov/page.cfm/MetandClimateDataSummary. 
HNF-54686

Revision 0

BPA, 2012, Midway-Benton No. 1 Transmission Line Rebuild Project,DOE/EA-1912, US Department of Energy Bonneville Power Administration, Portland, Oregon. Online at http://energy.gov/nepa/ea1912-midway-benton-no-1-rebuild-project-near-town-desert-aire-benton-county-wa.

USGS, 2011, USGS Real-Time Water Data for Washington, U.S. Geological Survey, Seattle, Washington. Online at http://waterdata.usgs.gov/wa/nwis.

WNHP, 2011, List of Vascular Plants Tracked by the Washington Natural Heritage Program, Washington Natural Heritage Program, Department of Natural Resources, Olympia, Washington. Online at http://www1.dnr.wa.gov/nhp/refdesk/lists/plantrnk.html. Accessed March 13, 2013

WNHP, 1999, Field Guide to Selected Rare Plants, Washington Natural Heritage Program, Department of Natural Resources, Olympia, Washingon. Online at http://www1.dnr.wa.gov/nhp/refdesk/fguide/htm/fgmain.htm.

WNHP, 2011, Confidential occurrence records for Rorippa columbiae, Washington Natural Heritage Program, Department of Natural Resources, Olympia, Washington. 